\title{
Implementasi Nilai-Nilai Tri Hita Karana dalam Model Pembelajaran Logan Avenue Problem Solving-Heuristik Berpengaruh Positif Terhadap Kemampuan Pemecahan Masalah Matematika
}

\author{
I.Dw.A Indah Gitatenia ${ }^{*}$, I. W. Wiarta ${ }^{2}$, I.B. Gede Surya Abadi ${ }^{3}$ (iD \\ ${ }^{123}$ Prodi Pendidikan Guru Sekolah Dasar, Universitas Pendidikan Ganesha, Singaraja, Indonesia \\ *Corresponding author: dewa.ayu.indah@undiksha.ac.id
}

\begin{abstract}
Abstrak
Penelitian ini bertujuan untuk mengetahui pengaruh yang signifikan model pembelajaran Logan Avenue Problem SolvingHeuristik berbasis Tri Hita Karana terhadap Kemampuan Pemecahan Masalah Matematika pada kelas V SD Negeri Gugus 1 Gianyar. Metode penelitian kuantitatif digunakan dengan desain nonequivalent pretest posttest control group design. Populasi yang digunakan adalah kelas V SD Negeri Gugus 1 Gianyar yang terdiri dari tujuh sekolah sebanyak 501 siswa. Teknik Cluster Random Sampling digunakan untuk menentukan sampel dan diperoleh kelas V di SD N 7 Gianyar sebagai kelompok eksperimen dan SD N 4 Gianyar sebagai kelompok kontrol. Pengumpulan data kemampuan pemecahan masalah matematika menggunakan metode tes berupa soal cerita yang telah divalidasi. Hasil perhitungan data post-test menunjukkan nilai rerata kelompok eksperimen lebih dari kelompok kontrol (eksperimen $=39,92>$ kontrol=35,87). Berdasarkan analisis uji-t diperoleh $t_{\text {hitung }}=4,11$ sedangkan pada taraf signifikansi $5 \%$ dan $\mathrm{dk}=82$ diperoleh nilai $\mathrm{t}_{\text {tabel }}(\alpha=0,05,82)=1,99$ ( $\mathrm{t}_{\text {hitung }}$ $\left.=3,674>t_{\text {tabel }}=1,99\right)$. Dengan demikian dapat disimpulkan bahwa terdapat pengaruh yang signifikan model pembelajaran Logan Avenue Problem Solving-Heuristik berbasis Tri Hita Karana terhadap kemampuan pemecahan masalah matematika pada kelas V SD Gugus I Gianyar. Kepada peneliti lain disarankan agar dapat menggunakan temuan hasil ini untuk melakukan kajian yang lebih mendalam terkait dengan penelitian ini.
\end{abstract}

Keywords: LAPS-Heuristik, Tri Hita Karana, Kemampuan Pemecahan Masalah Matematika

\section{Abstract}

This study studied to study the significant influence of the Tri Hita Karana-based Logan Avenue Problem Solving-Heuristic learning model on the Mathematical Problem Fulfillment Ability in the fifth grade of SD Negeri 1 Gianyar. Quantitative research methods are used with non-equivalent pretest posttest control group design. The population used is the fifth grade of SD Negeri 1 Gianyar Cluster consisting of seven schools totaling 501 students. The Random Sampling Cluster technique was used to determine the sample and obtain grade $V$ in SD $N 7$ Gianyar as the experimental group and SD N 4 Gianyar as the control group. Data collection ability to solve mathematical problems using the method of story questions that have been validated. The results of the posttest data calculation showed the average value of the experimental group more than the control group (experiment $=39.92>$ control $=35.87$ ). Based on the $t$-test analysis obtained tcount $=4.11$ while at a significance level of $5 \%$ and $d k=82$ obtained $t$-table $(\alpha=0.05,82)=1.99$ (tcount $=3.674>$ ttable $=$ 1.99). Thus it can be concluded that there is a significant influence of the Tri Hita Karana-based Logan Avenue Problem Solving-Heuristic learning model on the ability to solve mathematical problems in class $V$ of Elementary School I Gianyar. Other researchers suggest that they can use the findings to conduct studies that are more related to this research.

Keywords: LAPS-Heuristics, Tri Hita Karana, Mathematical Problem Solving Ability

\section{Pendahuluan}

Pentingnya pendidikan sudah disadari oleh seluruh masyarakat Indonesia karena pendidikan berperan sebagai penghasil sumber daya manusia yang berkualitas (Astianawan et al., 2016). Pendidikan dapat menanamkan rasa tanggung jawab yang tinggi karena dengan pendidikan seseorang mampu mengambil sebuah keputusan dan pendidikan juga dapat dikatakan sebagai investasi jangka panjang yang memerlukan usaha yang keras untuk meraihnya (Rila Cahya et al., 2019). Berdasarkan UU No. 20 Tahun 2003 tentang Sistem

$\begin{array}{lll}\text { History: } & & \text { Publisher: Undiksha Press } \\ \text { Received } & : \text { 4 Juli } 2020 & \text { Licensed: This work is licensed under } \\ \text { Revised } & : \text { 15 Juli } 2020 & \text { a Creative Commons Attribution 3.0 License } \\ \text { Accepted } & : \text { 26 Agustus } 2020 & \text { CC } \\ \text { Published } & : \text { 25 September } 2020 & \text { SA }\end{array}$


Pendidikan Nasional, menyatakan fungsi pendidikan nasional adalah untuk menyempurnakan potensi dan karakter bangsa dengan tujuan menciptakan manusia yang berbakti kepada tuhan dan menjadi pribadi yang lebih baik dalam menjadi warga Negara Indonesia. Dengan adanya UU ini, diharapkan agar anak-anak bangsa siap untuk menjadi manusia yang unggul dalam bidangnya masing masing dan memiliki kepribadian yang berkarakter.

Pendidikan yang sistematis disebut dengan pendidikan formal. Sekolah Dasar adalah pondasi dasar dalam pendidikan formal yang dididik atau dibelajarkan oleh guru yang peranannya sangat penting dalam menanamkan konsep-konsep dasar bagi siswa (Ardiantari et al., 2015). Sekolah Dasar (SD) merupakan lembaga pendidikan yang siswanya berumur berkisar antara 7 tahun sampai dengan 13 tahun pada fase operasional konkrit (Winursiti, 2017). Dalam pendidikan di susunlah sebuah rencana tertulis yakni kurikulum yang digunakan untuk mencapai tujuan dari pendidikan. Pendidikan di Indonesia saat ini melaksanakan atau menerapkan kurikulum 2013 (Yunita Sari et al., 2019).

Kurikulum 2013 disusun dengan tujuan mendidik potensi manusia khususnya siswa agar menjadi pribadi yang bertakwa kepada tuhan dan dapat berpartisipasi dalam kehidupan bermasyarakat dengan sikap yang kreatif dan inovatif. Nilai sikap, pengetahuan, dan keterampilan yang merujuk pada kompetensi lebih ditekankan pada kurikulum ini (Permendikbud Nomor 57 Tahun 2014). Kurikulum 2013 berorientasi pada pendekatan saintifik, pendekatan saintifik menempatkan siswa menjadi subjek yang berperan aktif dalam proses pembelajaran berlandaskan 5M yakni mengamati, menanya, mengumpulkan informasi, mengasosiasi, dan mengkomunikasikan (Ulia, 2016). Kurikulum 2013 terus diperbaharui sehingga pembelajaran tematik mengalami perubahan yakni memisahkan pelajaran matematika pada kelas tinggi karena pada pelajaran matematika diperlukan pemahaman konsep yang lebih mendalam. Kegiatan pembelajaran merupakan inti pada proses pendidikan, oleh karena itu kegiatan pembelajaran harus menjadi perhatian utama dalam setiap peningkatan kualitas pendidikan di SD (Kuswari \& ., 2019).

Mata pelajaran yang wajib diajarkan pada semua jenjang pendidikan adalah matematika (Listiani et al., 2014). Matematika merupakan suatu ilmu yang memiliki peran penting dalam kehidupan baik dari sisi kehidupan praktis dan sisi Matematika sebagai proses berpikir (Riastini \& Mustika, 2017). Pembelajaran hitung menghitung atau secara formal disebut pendidikan matematika ialah ilmu yang sudah pasti kebenarannya atau memiliki jawaban yang mutlak yang sangat erat kaitannya dengan permasalahan sehari hari di sekolah (Dwiningrat et al., 2013). Pada pelaksanaanya, pelajaran ini dapat menggali pengetahuan seseorang dalam menyelesaikan suatu permasalahan yang berhubungan dengan hitung menghitung atau angka dan memberi manfaat yang sangat berguna dalam menyelesaikan suatu permasalahan di dalam kehidupan bermasyarakat. Pada jenjang terendah yakni jenjang sekolah dasar harus diterapkan atau diajarkan proses pemecahan masalah matematika karena pada jenjang ini akan membuat konsep pemecahan masalah matematika akan tertanam pada diri siswa hingga jenjang-jenjang berikutnya (Oktafrianto et al., 2018). Pemecahan masalah merupakan bagian dari pembelajaran matematika yang sangat penting karena dalam proses pembelajaran atau penyelesaiannya siswa dapat menggunakan pengetahuan dan pengalaman yang sudah dimiliki (Putri et al., 2019). Terdapat empat langkah penyelesaian dalam proses pemecahan masalah yaitu memahami masalah, merencanakan masalah, menyelesaikan masalah sesuai rencana dan melakukan pengecekan kembali terhadap semua langkah yang dikerjakan (Hidayat \& Sariningsih, 2018). Melalui pemecahan masalah, siswa mendapatkan pengalaman belajar yang lebih bermakna (Riastini \& Mustika, 2017).

Pendidikan matematika dipandang sulit oleh siswa di sekolah, dikarenakan banyak komponen matematika seperti teoritis, lambang-lambang dan rumus-rumus sulit yang harus diselesaikan di setiap persoalannya serta rendahnya kemampuan siswa dalam memecahkan persoalan matematika (Gazali, 2016). Rendahnya kemampuan matematika menyebabkan 
munculnya sikap ketidaksenangan siswa terhadap pelajaran matematika (Ulya, 2015). Pandangan ini diketahui dari hasil kognitif atau hasil belajar siswa yang masih rendah dan banyaknya siswa yang kesulitan mengerjakan soal khususnya pelajaran matematika (Oktaviani et al., 2019). Selain itu, pembelajaran matematika juga hanya menitikberatkan kepada guru sehingga siswa cepat lupa karena siswa tidak mengkonstruksi pengetahuannya sendiri. Pelajaran matematika seharusnya menjadi salah satu mata pelajaran yang menyenangkan dan digemari oleh siswa karena dalam penerapannya sangatlah sederhana dan dapat diaplikasikan dalam kehidupan sehari-hari (Muliandari, 2019).

Stigma terhadap sulitnya pembelajaran matematika perlu ditindaklanjuti, maka dari itu peranan guru dalam menghilangkan stigma pada pembelajaran matematika tersebut harus ditingkatkan. Guru perlu memiliki kemampuan untuk menyederhanakan penjelasan dan membuat pembelajaran menarik karena guru juga berperan sebagai fasilitator yang menentukan keberhasilan dalam pembelajaran (Rini et al., 2019). Guru juga perlu melakukan inovasi pada model pembelajaran dengan harapan dapat memudahkan siswa dalam memahami pendidikan matematika. Kemampuan pengelolaan kelas yang baik juga harus dikuasai oleh guru sehingga siswa dapat berpartisipasi aktif dalam pembelajaran khususnya pelajaran matematika (Arthaningsih \& Diputra, 2019).

Berdasarkan wawancara dan pengamatan yang telah dilaksanakan pada hari senin, tanggal 11 November 2019 bersama guru kelas V di SD Gugus I Gianyar diperoleh informasi bahwa kreativitas siswa dalam pelajaran matematika kurang atau dikatakan keaktifan siswa masih kurang. Hal ini dikarenakan kurangnya kemauan dan ketertarikan siswa terhadap pelajaran matematika serta kurangnya keterampilan siswa pada saat menyelesaikan suatu permasalahan matematika yang diajukan oleh guru. Faktanya dilihat dari 51,90\% dari 501 siswa yang menunjukan bahwa nilai mata pelajaran matematika dibawah KKM.

Bukti lainnya dilihat dari banyaknya siswa yang kesulitan untuk menentukan masalah dan merumuskannya, sehingga siswa tidak dapat menyelesaikan soal yang diberikan. Beberapa siswa juga hanya mengandalkan jawaban teman dan tidak akan mengerjakan tugasnya apabila ia tidak mengerti. Hal-hal ini menerangkan bahwa kemampuan siswa untuk menentukan karakteristik soal matematika dan mencari penyelesaiannya masih belum terlihat artinya kemampuan siswa dalam menyelesaikan suatu permasalahan masih kurang baik. Selain dikarenakan oleh faktor dari dalam diri siswa (internal), faktor dari luar (eksternal) juga dapat menimbulkan kesulitan dalam memecahkan suatu permasalahan matematika seperti kurikulum, program, model pembelajaran, guru, sarana dan prasarana. Secara umum proses pembelajaran Matematika di kelas dominan berpusat pada guru dan Guru selalu mengajar Matematika dengan metode ceramah (Gunantara et al., 2014). Berdasarkan penyataan dan hasil observasi guru SD Gugus 1 Gianyar cenderung menggunakan metode ceramah dan focus siswa hanya berpusat pada guru pada saat pelajaran matematika.

Permasalahan ini membutuhkan suatu solusi yang tepat, baik untuk faktor internal dan eksternalnya agar siswa mampu untuk meningkatkan keterampilan pemecahan masalah matematika, aktif mempelajari matematika dan juga melatih kejujuran dalam mengembangkan karakter. Maka dari itu, diperlukan inovasi pembelajaran khususnya model pembelajaran yang dirasa mampu untuk mengaktifkan kemampuan siswa dalam menyelesaikan permasalahan matematika dan perlunya bantuan yang menumbuh kembangkan karakter siswa.

Berdasarkan permasalahan yang ada, maka untuk menumbuh kembangkan kemampuan siswa dalam memecahkan suatu permasalahan di sekolah, peneliti memilih model pembelajaran Logan Avenue Problem Solving-Heuristik untuk digunakkan. Logan Avenue Problem Solving-Heuristik atau dapat disingkat LAPS-Heuristik adalah model pembelajaran pemecahan masalah matematika yang menekankan pada pencarian alternatifalternatif yang berupa pertanyaan-pertanyaan yang dapat digunakan untuk pemecahan 
masalah (Gilang Azwardi, 2019). Model ini menuntun pada proses penyelesaian suatu permasalahan yang dilakukan dari beberapa tahap, dimulai dari melakukan pemahaman terhadap permasalahan hingga mendapatkan solusi dari permasalahannya (Suryani \& Iqbal, 2018).

Keunggulan dari model pembelajaran Logan Avenue Problem Solving-Heuristik (Shoimin, 2014), yaitu 1) Dapat menciptakan dan menumbuhkan rasa keingintahuan siswa dalam berkreasi. 2) Dapat meningkatkan keterampilan membaca dan pembuatan pertanyaan yang benar. 3) Dapat menambah wawasan baru serta membuat jawaban yang baru, asli, khas, dan beraneka ragam. 4) Dapat meningkatkan penerapan ilmu yang dimiliki siswa secara optimal. 5) Penggunaan tahapan dalam memecahkan suatu permasalahan yang sistematis membuat siswa menjadi mampu dalam menganalisis suatu permasalahan sehingga siswa dapat melakukan evaluasi. 6) Dapat mengarahkan siswa dalam memberikan pengalaman dengan melakukan kegiatan yang bermakna.

Penerapan suatu model pembelajaran dirasa akan lebih lengkap apabila dikombinasikan dengan suatu unsur pembelajaran. Kombinasi yang peneliti ambil untuk melengkapi model pembelajaran Logan Avenue Problem Solving-Heuristik adalah kombinasi dengan konsep Tri Hita Karana (Astami et al., 2016). Konsep Tri Hita Karana ini adalah suatu konsep kearifan lokal dari daerah bali yang mengajarkan manusia untuk menjaga tiga hubungan harmonis (Yunita Sari et al., 2019). Dalam Tri Hita Karana terdapat tiga unsur yang terdiri dari parahyangan yakni hubungan harmonis antara manusia dengan tuhan, pawongan yakni harmonis sesama manusia, dan palemahan harmonis antara manusia dengan lingkungan (Putra, 2019). Model pembelajaran Logan Avenue Problem Solving-Heuristik yang dipadukan bersama konsep Tri Hita Karana akan mampu membantu siswa menemukan sendiri solusi dari persoalan yang ditemui (discovery) dan dengan menerapkan konsep Tri Hita Karana dapat menjadikan siswa pribadi yang berkarakter.

Berdasarkan kondisi di atas, maka dikaji lebih dalam permasalahannya dengan penelitian ini yang berjudul "Pengaruh Model Pembelajaran Logan Avenue Problem Solving-Heuristik Berbasis Tri Hita Karana Terhadap Kemampuan Pemecahan Masalah Matematika Kelas V di SD Gugus I Gianyar Tahun Ajaran 2019/2020”. Adapun tujuan dari penelitian ini adalah untuk mengetahui pengaruh yang signifikan model pembelajaran Logan Avenue Problem Solving-Heuristik berbasis Tri Hita Karana terhadap kemampuan pemecahan masalah matematika kelas V di SD Gugus I Gianyar Tahun Ajaran 2019/2020.

\section{Metode}

Pelaksanaan penelitian ini diterapkan pada kelas V di SD Negeri Gugus I Gianyar. Jadwal kegiatan pelaksanaan penelitian ini pada semester genap tahun ajaran 2019/2020 dari Januari sampai Februari pada kelompok sampel. Penelitian yang dilakukan adalah penelitian dengan jenis kuantitatif yakni dengan "quasi eksperiment" eksperimen semu. Penelitian Eksperimen semu merupakan penelitian yang paling sedikit dapat dilakukan dalam penelitian dengan satu kondisi yang dapat dimanipulasikan, sementara pada kondisi lainnya dianggap konstan dan juga perbedaan kondisi ataupun variabelnya dapat diukur yang artinya dalam kondisi kelompok eksperimen tidak semua variabel dapat dikontrol peneliti (Wulandari et al., 2020). Penelitian ini menggunakan Kelompok kontrol dalam rancangan ini tidak berfungsi secara menyeluruh dalam mengontrol variabel luar yang dapat mempengaruhi kegiatan penelitian eksperimen (Sugiyono, 2017a).

Desain eksperimen ini menggunakan "Nonequivalent Pretest Posttest Control Group Design". Dalam hal ini, peneliti tidak memungkinkan untuk memilih partisipan untuk dilibatkan dalam kelompok eksperimen ataupun kelompok kontrol, sehingga sistem pengundian dilakukan dalam penentuan kelompok-kelompoknya. 
Desain penelitian ini terdapat kelompok belajar yang diberi perlakuan model Logan Avenue Problem Solving-Heuristik dan kelompok belajar yang menggunakan model konvensional yang dijadikan sebagai pengontrol. Kelompok-kelompok ini kemudian memperoleh pre-test dan post-test dengan menggunakan Instrumen kemampuan pemecahan masalah matematika yang sebelumnya telah di uji coba, yang digambarkan pada rancangan Gambar 1.

\begin{tabular}{lll}
$\mathrm{O} 1$ & $\mathrm{X}$ & $\mathrm{O} 2$ \\
\hline $\mathrm{O} 3$ & - & $\mathrm{O} 4$
\end{tabular}

Gambar 1. Desain Penelitian Eksperimen Semu Menggunakan Nonequivalent Pretest Posttest Control Group Design

Keterangan :

$\mathrm{O} 1=$ Pretest Kelompok Eksperimen

$\mathrm{X}=$ Treatment/Perlakuan

$\mathrm{O} 2=$ Posttest Kelompok Eksperimen

$\mathrm{O} 3=$ Pretest Kelompok Kontrol

- $\quad=$ Non Treatment/Tanpa Perlakuan

$\mathrm{O} 4=$ Posttest Kelompok Kontrol

Equivalent atau penyetaraan kelompok dilakukan dengan cara memberikan pre-test (Dantes, 2014). Uji-t ialah teknik yang diterapkan dalam penyetaraan kelompok pada penelitian ini. Dengan demikian, maka rancangan ini hanya menitik beratkan pada skor posttest yang dilakukan pada akhir perlakuan pada penelitian tanpa memperhitungkan skor pretest. Beberapa tahapan-tahapan pada penelitian terdiri dari tahap awal/persiapan, tahap pelaksanaan dan tahap akhir. Pada tahap awal/persiapan terdiri dari melaksanakan wawancara dan pengamatan di seluruh sekolah SD Negeri Gugus I Gianyar, mendiskusikan materi dan penyusunan RPP beserta LKS bersama guru, mengkonsultasikan instrument/alat yang digunakan untuk pre-test dan post-test bersama dengan wali kelas dan dosen pembimbing, menentukan sampel penelitian dari populasi dengan teknik cluster random sampling, melaksanakan uji instrumen pada kelas VI di SD N 7 Gianyar, melaksanakan pretest kepada sampel yang terpilih untuk membuktikan kesetaraan kelompok, dan menentukan sampel dengan cara undian sederhana dalam penentuan kelompok eksperimen dan kontrol. Kemudian pada tahap pelaksanaan, kegiatan yang dilakukan terdiri dari memberikan perlakuan di kelas V kelompok eksperimen berupa Model Pembelajaran LAPS-Heuristic berbasis Tri Hita Karana, memberikan perlakuan di kelas V kelompok kontrol berupa pembelajaran konvensional dan melaksanakan post-test di kegiatan akhir eksperimen kepada kedua kelompok. Pada tahap akhir, kegiatan yang dilakukan adalah menganalisis data yang telah dikumpulkan dari hasil penelitian dan menguji hipotesis.

Langkah awal dalam pelaksanaan penelitian ini adalah menentukan populasi untuk diteliti. Populasi ialah objek/subjek yang terdapat pada wilayah generalisasi yang memiliki bobot dan karakteristik tertentu kemudian dijadikan pelajaran dan selanjutnya dilakukan penarikan suatu kesimpulan (Sugiyono, 2017b). Pada penelitian ini dipilihlah semua kelas V di SD Gugus I Gianyar Tahun 2019/2020 sebagai Populasi sebanyak 501 siswa yang terdiri dari tujuh sekolah yakni SD N 1 Gianyar, SD N 2 Gianyar, SD N 3 Gianyar, SD N 4 Gianyar, SD N 5 Gianyar, SD N 6 Gianyar, SD N 7 Gianyar . Penentuan sampel yang terbentuk dari populasi pada penelitian ini adalah menggunakan teknik "Cluster Random Sampling” yaitu merandom kelas. Penentuan sampel bukan dilakukan pengacakan individu melainkan pengacakan kelas. Pengundian dilakukan dengan cara menulis semua nama kelas V pada 
masing-masing sekolah di SD Negeri Gugus 1 Gianyar yang dijadikan populasi pada masingmasing kertas, kemudian kertas digulung. Nama-nama dalam gulungan kertas tersebut merupakan sampel penelitian. Gulungan kertas tersebut dimasukan ke dalam kotak dan dikocok. Pemilihan kelompok sampel penelitian ini tidak dilakukan pengacakan individu melainkan hanya pengacakan kelas. Setelah mendapatkan hasil undian dan terpilih dua kelompok yang dijadikan sampel penelitian yakni SD N 7 Gianyar dan SD N 4 Gianyar, dilakukan penyetaraan kelompok dengan melakukan pre-test, hasil pre-test dianalisis menggunakan uji-t kemudian penulis melakukan pengundian dari 2 sampel tersebut untuk memilih kelompok eksperimen dan kontrol.

Sebelum dilakukannya penyetaraan, hasil pre-test data kedua kelompok sampel harus diuji kenormalan dan kehomogenannya dengan menggunakan uji normalitas sebaran data dan uji homogenitas yang kedua pengujian tersebut termasuk kedalam uji prasyarat. Kemudian barulah dilakukan penyetaraan menggunakan uji-t. Berdasarkan perhitungan yang telah dilakukan, nilai pre-test siswa pada kelas V SD Negeri 7 Gianyar diperoleh nilai maksimum | Fr - Fs $\mid=0,176$ dan pada taraf signifikansi 5\% dan nilai harga penguji pada tabel Kolmogorov smirnov untuk $\mathrm{n}=39$ diperoleh nilai tabel 0,218. Karena nilai maksimum $\mid \mathrm{Fr}-$ Fs $\mid=0,176<$ nilai tabel Kolmogorov $=0,218$ maka data hasil pre-test berdistribusi normal. Sedangkan perhitungan hasil uji normalitas sebaran data pre-test siswa pada kelas V SD Negeri 4 Gianyar diperoleh nilai maksimum $\mid$ Fr - Fs $\mid=0,145$ dan pada taraf signifikansi 5\% dan nilai harga penguji pada tabel Kolmogorov smirnov untuk $\mathrm{n}=45$ diperoleh nilai tabel 0,203. Karena nilai maksimum $|\mathrm{Fr}-\mathrm{Fs}|=0,145<$ nilai tabel Kolmogorov $=0,203$ maka data hasil pre-test berdistribusi normal. Setelah kedua kelompok sampel dinyatakan normal maka selanjutnya dilakukan uji homogenitas dengan menggunakan Uji-F. Perhitungan yang telah dilakukan diperoleh harga nilai $F_{\text {hitung }}=0,97$ dan $F_{\text {tabel }}=1,66$. Maka $F_{\text {hitung }}=0,97<$ $\mathrm{F}_{\text {tabel }}=1,66$ artinya varians data kemampuan pemecahan masalah matematika antara kedua kelompok adalah sama/homogen.

Setelah memenuhi uji prasyarat yakni data nilai pre-test kedua kelompok sampel tersebut dinyatakan normal dan homogen. Kemudian uji kesetaraan dilakukan dengan menggunakan uji-t. Hasil analisis didapat $t_{\text {hit }}=1,46$ dan $t_{\text {tab }}=1,99$, maka $t_{\text {hitung }}<t_{\text {tabel }}(1,46<$ 1,99) yang menyatakan bahwa kedua kelompok setara. Maka dilakukan pengundian kembali sehingga diperoleh kelas V SD N 7 Gianyar sebagai kelompok eksperimen dan kelas V SD N 4 Gianyar kelompok kontrol.

Metode/teknik penelitian sangatlah penting dilakukan agar dapat menghindari kesalahan yang dilakukan dalam proses pengumpulan data. Metode penelitian ialah upaya yang bersifat ilmiah dalam pengumpulan data yang berguna untuk keperluan tertentu (Sugiyono, 2017a). Metode pengumpulan data dapat mempergunakan berbagai macam metode seperti kuesioner, pengamatan, wawancara, tes, analisis dokumen dan sebagainya. Penggunaan metode tes di dalam penelitian ini diartikan sebagai suatu cara pengumpulan data dengan pemberian tugas kepada seseorang atau kelompok yang harus dikerjakan (Agung, 2014) Metode tes adalah pemerolehan data dengan cara pemberian tugas atau pertanyaan kepada testee yakni orang yang berpartisipasi dalam tes sehingga menghasilkan suatu skor (interval) (Agung, 2014). Metode tes ialah upaya pengumpulan data dalam bentuk pemberian tugas yang dilakukan seseorang atau sekelompok orang yang akan di tes. Tes tersebut kemudian mendapatkan data berupa skor yakni data interval. Pada penelitian ini metode tes berfungsi untuk mendapatkan gambaran berbentuk skor mengenai pemahaman siswa akan suatu masalah matematika dan untuk lebih mengetahui keterampilan siswa dalam menyelesaikan permasalahan matematika (Kemampuan Pemecahan Masalah Matematika). Tes adalah alat untuk melakukan pengukuran objektif dalam menilai perilaku seseorang, kemudian nilai dari perilaku tersebut dapat digambarkan melalui bantuan angka, skala atau dengan system kategori (Yusuf, A. Muri, 2015). Tes yang digunakan sebagai alat ukur 
dengan memperhatikan peraturan yang telah ditentukan (Arikunto, 2016). Instrumen yang dibuat berbentuk tes uraian (soal cerita) kemampuan pemecahan masalah matematika yang berfungsi untuk mengukur keahlian yang dimiliki siswa dalam menyelesaikan suatu persoalan matematika. Tes yang dibagikan kepada siswa pada kelompok eksperimen dan kontrol sebelumnya harus diujicobakan dengan tujuan validasi instrumen. Validasi instrumen dilakukan dengan uji validitas dan uji reliabilitas. Dari 10 butir tes yang diujikan didapat 6 butir tes valid dan 4 butir tes tidak valid yang digunakan untuk perolehan data Pre-test dan Post-test.

\section{Hasil dan Pembahasan}

Hasil penelitian yang telah dilakukan di SD N 7 Gianyar sebagai kelompok eksperimen yang menerapkan Model Pembelajaran Logan Avenue Problem Solving-Heuristik berbasis Tri Hita Karana dan di SD N 4 Gianyar sebagai kelas kontrol menerapkan pembelajaran konvensional untuk memperoleh data kemampuan pemecahan masalah matematika dengan pemberian perlakuan sebanyak masing-masing 6 kali. Adapun rekapitulasi hasil analisis data post-test kemampuan pemecahan masalah matematika kelompok eksperimen dan kelompok kontrol sebagai berikut.

Tabel 1. Rangkuman Statistik Deskriptif Kemampuan Pemecahan Masalah Matematika

\begin{tabular}{lcc}
\hline \multicolumn{1}{c}{ Statistik Deskriptif } & Kelompok Eksperimen & Kelompok Kontrol \\
\hline Banyak Siswa & 39 & 45 \\
Rata-rata Post test & 39,92 & 35.87 \\
Standar Deviasi & 6,61 & 7.24 \\
Varians & 43,81 & 52.34 \\
Nilai Skor Minimum & 28 & 24 \\
Nilai Skor Maksimum & 53 & 49 \\
\hline
\end{tabular}

Berdasarkan Tabel 1, maka data tersebut dikonversikan dengan PAN skala 5 mempergunakan perhitungan rata-rata diperoleh sebagai berikut

Tabel 2. Konversi PAN dengan Skala 5

\begin{tabular}{cccc}
\hline $\begin{array}{c}\text { Rentangan Kelompok } \\
\text { Eksperimen }\end{array}$ & $\begin{array}{c}\text { Rentangan } \\
\text { Kelompok Kontrol }\end{array}$ & $\begin{array}{c}\text { Nilai Angka/ } \\
\text { Huruf }\end{array}$ & Predikat \\
\hline $49,98-<60,05$ & $46,85-<57,83$ & $4=\mathrm{A}$ & Sangat Baik \\
$43,27-<49,98$ & $39,53-<46,85$ & $3=\mathrm{B}$ & Baik \\
$36,56-<43,27$ & $32,21-<39,53$ & $2=\mathrm{C}$ & Cukup \\
$29,85-<36,56$ & $24,89-<32,21$ & $1=\mathrm{D}$ & Kurang \\
$19,79-<29,85$ & $13,91-<24,89$ & $0=\mathrm{E}$ & Sangat Kurang \\
\hline
\end{tabular}

Hasil dari penelitian ini didapat dari kelompok eksperimen dan kontrol yang samasama diberi pre-test dan post-test. Data data yang telah didapatkan kemudian diolah menjadi data gain skor ternormalisasi. Perolehan hasil analisis perhitungan gain skor kemampuan pemecahan masalah matematika pada kelompok eksperimen diperoleh rerata 39,92 dan kelompok kontol 35.87 yang kemudian dikonversikan kedalam Penilaian Acuan Norma (PAN) skala 5, diperoleh predikat Cukup pada kelompok eksperimen dengan rentang 36,56 $<43,27$ dan pada kelompok kontrol juga dikategorikan Cukup dengan rentang 32,21 -< 39,53. Kelompok-kelompok tersebut sama sama berada pada predikat Cukup. Kelompokkelompok tersebut sama sama berada pada predikat Cukup, hal ini terjadi karena kedua kelompok menggunakan kurikulum yang sama yaitu kurikulum 2013 dan juga pembelajaran 
muatan matematika pada materi volume bangun ruang di kelompok eksperimen dan kontrol menerapkan pembelajaran dengan pendekatan yang sama yaitu pendekatan saintifik.

Data nilai kemampuan pemecahan masalah matematika menunjukkan bahwa kelompok yang dibelajarkan menggunakan model pembelajaran Logan Avenue Problem Solving-Heuristik memiliki nilai rata-rata lebih tinggi dari kelompok yang dibelajarkan menggunakan pembelajaran konvensional. Selanjutnya dapat dilakukan uji hipotesis. Dalam pengujian hipotesis sebelumnya harus memenuhi uji prasyarat analisis diantaranya uji normalitas sebaran data serta homogenitas varians. Rekapitulasi hasil uji normalitas sebaran data Kemampuan Pemecahan Masalah Matematika kelompok eksperimen dan kontrol disajikan disajikan pada Tabel 3.

Tabel 3. Rekapitulasi Hasil Uji Normalitas Sebaran Data

\begin{tabular}{clccc}
\hline No. & Sampel & $\begin{array}{c}\text { Nilai Maksimum } \\
\mid \text { Ft-Fs } \mathbf{~}\end{array}$ & $\begin{array}{c}\text { Nilai Tabel } \\
\text { Kolmogorov-Smirnov }\end{array}$ & Keterangan \\
\hline 1. & $\begin{array}{l}\text { Kelompok } \\
\text { Eksperimen }\end{array}$ & 0,144 & 0,218 & $\begin{array}{c}\text { Berdistribusi } \\
\text { normal } \\
\text { Berdistribusi } \\
\text { normal }\end{array}$ \\
\hline
\end{tabular}

Berdasarkan hasil pengujian normalitas kelompok eksperimen, didapat nilai $|\mathrm{Fr}-\mathrm{Fs}|$ terbesar $=0,144$. Dengan taraf signifikansi $5 \%$ dan $n=39$ didapat nilai tabel kolmogorov smirnov $=0,218$. Hal tersebut menunjukkan bahwa $|\mathrm{Fr}-\mathrm{Fs}|$ terbesar $<$ tabel kolmogorov smirnov yang artinya data berdistribusi normal.

Hasil uji normalitas kelompok kontrol, didapatkan nilai $|\mathrm{Fr}-\mathrm{Fs}|$ terbesar $=0,156$. Pada taraf signifikansi 5\% dan $\mathrm{n}=45$ didapat nilai tabel kolmogorov smirnov $=0,203$. Hal tersebut menunjukkan bahwa $|\mathrm{Fr}-\mathrm{Fs}|$ terbesar < tabel kolmogorov smirnov yang artinya data distribusi normal.

Data pada kelompok eksperimen dan kontrol telah dinyatakan berdistribusi normal maka selanjutnya dilakukan pengujian homogenitas varians. Pelaksanaan pengujian homogenitas varians, dimaksudkan untuk membuktikan perbedaan varians-lah yang menjadi penyebab perbedaan pada uji hipotesis dan bukan disebabkan oleh perbedaan di dalam kelompok itu sendiri. Uji Fisher (F) digunakan untuk menguji homogenitas varians. Melalui taraf signifikansi $5 \%$ dengan derajat kebebasan pembilang $n_{1}-1$ serta derajat kebebasan pada penyebut $n_{2}-1$. Dengan ketentuan apabila $F_{\text {hitung }}>F_{\text {tahel. }}$ maka sampel tidak homogen dan apabila $F_{\text {hitung }}<F_{\text {thhel }}$ maka sampel homogen. Rekapitulasi hasil perhitungan uji homogenitas pada kelompok sampel penelitian disajikan pada Tabel 4 sebagai berikut.

Tabel 4. Rekapitulasi Uji Homogenitas Varians Sampel Penelitian

\begin{tabular}{ccccccc}
\hline No. & \multicolumn{1}{c}{ Sampel } & Varians & DK & F $_{\text {hitung }}$ & F $_{\text {tabel }}$ & Keterangan \\
\hline 1. & Kelompok Eksperimen & 0.0132 & 38 & \multirow{2}{*}{1,128} & \multirow{2}{*}{1,674} & \multirow{2}{*}{ Homogen } \\
2. & Kelompok Kontrol & 0.0117 & 44 & & & \\
\hline
\end{tabular}

Hasil dari analisis yang telah dilakukan, didapatkan $F_{\text {hitung }}=1,128$ dan $F_{\text {tabel }}=1,674$ dengan taraf signifikansi $5 \%$ dengan dk pembilang $\mathrm{n}_{1}-1(39-1=38)$ serta dk penyebut $\mathrm{n}_{2}-1$ (45-1 =44). Hal ini berarti $F_{\text {hitung }}=1,128<\mathrm{F}_{\text {tabel }}=1,674$, sehingga dapat dikatakan bahwa data masing masing kelompok yang diujikan memiliki varians yang homogen. Berdasarkan 
uji prasyarat diperoleh hasil data kelompok eksperimen dan kontrol berdistribusi normal serta memiliki varians homogen. Perolehan data tersebut sudah memenuhi uji prasyarat analisis sehingga dapat melakukan uji hipotesis menggunakan analisis statistik parametrik dengan ujit polled varians. Rekapitulasi hasil uji-t pada kedua kelompok sampel disajikan pada Tabel 5.

Tabel 5. Rekapitulasi Uji-T Sampel Penelitian

\begin{tabular}{ccccccccc}
\hline No. & Sampel & N & DK & Rata-rata & Variansi & $\mathbf{T}_{\text {hitung }}$ & $\mathbf{T}_{\text {tabel }}$ & Simpulan \\
\hline 1. & Kelompok & 39 & & 0.57 & 0.0132 & & & \\
$\begin{array}{l}\text { Eksperimen } \\
\text { Kelompok }\end{array}$ & 45 & 82 & & 0.48 & 0.0117 & 3,674 & 1,99 & $\mathrm{H}_{0}$ ditolak \\
Kontrol & 45 & & & & \\
\hline
\end{tabular}

Berdasarkan perhitungan uji-t yang telah dilakukan, didapatkan hasil analisis uji-t yakni $t_{\text {hit }}=3,674$ dan nilai $t_{\text {tab }}$ melalui taraf signifikansi 5\% dan dk $=\mathrm{n} 1+\mathrm{n} 2-2=39+45-2=$ 82 menunjukkan nilai sebesar 1,99. Sehingga diperoleh hasil $t_{\text {hit }} 3,674>t_{\text {tab }} 1,99$ maka $\mathrm{H}_{0}$ ditolak. Hal tersebut membuktikan bahwa terdapat pengaruh yang signifikan model pembelajaran Logan Avenue Problem Solving-Heuristik berbasis Tri Hita Karana terhadap kemampuan pemecahan masalah matematika siswa kelas V di SD Negeri Gugus I Gianyar Tahun Ajaran 2019/2020. Hal tersebut juga menunjukkan bahwa adanya perbedaan yang signifikan kemampuan pemecahan masalah matematika antara kedua kelompok yang diberi perlakuan berbeda.

Nilai rata-rata post-test kelompok eksperimen yang diberi perlakuan berupa penerapan model Logan Avenue Problem Solving-Heuristik berbasis Tri Hita Karana lebih tinggi dibandingkan dengan kelompok kontrol yang menggunakan pembelajaran konvensional sebesar $\bar{X}=39,92>\bar{X}=35,87$. Hal tersebut terjadi dikarenakan pembelajaran konvensional yang diberikan pada kelompok kontol belum optimal untuk diterapkan sebagai model pembelajaran. Pada saat kegiatan pembelajaran berlangsung cenderung hanya satu arah yaitu berpusat pada guru, sehingga membuat pembelajaran menjadi membosankan serta kreativitas siswa dalam pelajaran matematika masih kurang atau dikatakan siswa masih belum aktif. Pada kelompok eksperimen diberikan pembelajaran menggunakan model Logan Avenue Problem Solving berbasis Tri Hita Karana yang merupakan suatu pembaharuan atau inovasi dalam model pembelajaran yang dampaknya sangat signifikan yaitu mampu membuat kegiatan belajar dalam empat tahapan menjadi lebih intensif. Selama kegiatan berlangsung, siswa diberikan permasalahan matematika yang berkaitan dengan lingkungan untuk didiskusikan bersama kelompoknya sehingga kreativitas siswa dalam kegiatan pembelajaran lebih mengingat dan mampu membuat atau menciptakan suasana belajar yang lebih efektif dan juga bermakna. Bermakna dalam artian setiap siswa dapat mengkonstruksi pengetahuannya sendiri pada setiap tahapannya.

Tahap pertama yakni mampu memahami pokok masalah. Kemudian diteruskan dengan merencanakan penyelesaian masalahnya sebagai aksi pada pada tahap kedua, siswa juga dapat melakukan kolaborasi untuk menambah ide-ide pengetahuan bersama kelompoknya. Siswa diberikan kebebasan untuk mencari alternatif jawaban sehingga kebebasan bereksplorasi tersebut memberikan siswa kegembiraan karena dapat berinteraksi dengan lingkungan belajarnya. Berikutnya dilanjutkan dengan tahap menjalankan rencana penyelesaian masalah yang telah ditetapkan pada tahap kedua akan dilangsungkan pada tahap ketiga ini. Siswa mendapatkan inovasi tersendiri untuk menyelesaikan masalah tersebut sehingga kreativitas siswa terbentuk secara individu. Terakhir, dilanjutkan dengan tahap pengecekan ulang hasil yang telah diperoleh, yang dimana pada tahap ini setiap siswa akan mengidentifikasi kesulitan yang dihadapi sehingga nantinya memperoleh kesimpulan atas 
kesulitan yang dialami tersebut dan memperoleh solusi yang tepat untuk mengatasi kesulitan tersebut. Dengan adanya tahapan tersebut, daya ingat siswa dalam mengingat materi akan meningkat dan sekaligus akan diaplikasikan pada kehidupan sehari-hari terutama pada halhal yang terkait dengan keperluan untuk menyelesaikan permasalahan yang berkaitan dengan persoalan menghitung atau matematika.

Perolehan hasil temuan yang didapatkan, dikuatkan dengan hasil kajian yang relevan. Penelitian yang diteliti oleh (Rahman et al., 2018) menunjukkan bahwa terdapat perbedaan yang signifikan model pembelajaran LAPS (Logan Avenue Problem Solving)-Heuristik terhadap Kemampuan Pemecahan Masalah Matematika. Berdasarkan kajian relevan yang sudah disampaikan di atas, model pembelajaran Logan Avenue Problem Solving-Heuristik berbasis Tri Hita Karana berpengaruh pada Kemampuan Pemecahan Masalah Matematika.

Berdasarkan uraian tersebut, dinyatakan bahwa pembelajaran yang menerapkan model Logan Avenue Problem Solving-Heuristik berbasis Tri Hita Karana pada pelajaran matematika, memiliki kelebihan pada penelitian ini yakni dapat mengoptimalkan kemampuan berpikir siswa dalam mengkonstruksikan pengetahuannya sendiri melalui serangkaian usaha berinteraksi dengan lingkungan belajar yang dapat membuat siswa berkarakter dan didukung oleh peranan guru dalam pemberian pemantapan serta pengulangan materi. Kelebihan ini dibuktikan dengan perbandingan rerata gain score dari kemampuan pemecahan masalah matematika yang menunjukan nilai rerata gain score kelompok eksperimen lebih tinggi dari pada kelompok kontrol.

\section{Simpulan}

Hasil analisis statistik deskriptif diperoleh bahwa skor rerata kemampuan pemecahan masalah matematika pada kelompok eksperimen sebesar 39,92 yang kemudian dikonversikan pada tabel PAN skala 5 (lima) diperoleh predikat Cukup baik yang terletak antara $36,56 \leq \underline{X}$ $\leq 43,27$. Sedangkan hasil analisis statistik deskriptif kelompok kontrol diperoleh rerata sebesar 35,87 yang kemudian dikonversikan pada tabel PAN skala 5 (lima) diperoleh predikat Cukup baik yang terletak antara $32,21 \leq \underline{X} \leq 39,53$. Hasil analisis statistik inferensial uji-t diperoleh bahwa nilai thitung sebesar 2,45 dan pada taraf signifikansi $5 \%$ dan $\mathrm{dk}=82$ diperoleh nilai $t_{\text {tabel }}(\alpha=0,05,82)=1,99\left(t_{\text {hitung }}=3,674>t_{\text {tabel }}=1,99\right)$. Nilai $t_{\text {hitung }}>t_{\text {tabel }}$ dan $\mathrm{H}_{0}$ ditolak dan $\mathrm{H}_{1}$ diterima. Dengan demikian dapat disimpulkan bahwa terdapat perbedaan yang signifikan kemampuan masalah matematika antara siswa yang dibelajarkan dengan model pembelajaran Logan Avenue Problem Solving-Heuristik berbasis Tri Hita Karana dengan siswa yang tidak dibelajarkan dengan model pembelajaran model pembelajaran Logan Avenue Problem Solving-Heuristik berbasis Tri Hita Karana. Dengan demikian dapat disimpulkan bahwa terdapat pengaruh yang signifikan model pembelajaran Logan Avenue Problem Solving-Heuristik berbasis Tri Hita Karana terhadap kemampuan pemecahan masalah matematika pada kelas V SD Gugus I Gianyar Tahun 2019/2020. Berdasarkan simpulan dalam penelitian, maka dapat disarankan sebagai berikut yang pertama Kepada Guru disarankan agar lebih berkreasi dalam memvariasikan kegiatan pembelajaran dengan model maupun metode seperti model Logan Avenue Problem Solving-Heuristik berbasis Tri Hita Karana untuk meningkatkan kualitas belajar sesuai dengan harapannya. Kedua Kepada Kepala Sekolah disarankan agar penelitian hasil penelitian ini dapat dijadikan dasar untuk mengambil kebijakan terhadap guru-guru dalam menerapkan strategi pembelajaran yang lebih efektif untuk meningkatkan kualitas proses dan hasil belajar peserta didik.

\section{Daftar Pustaka}

Agung, A. A. G. (2014). Metodologi Penelitian. Yogyakarta: Aditya Media Publishing.

Agung, A. A. G. (2015). Buku Ajar Desain dan Analisis Eksperimen. Singaraja: Undiksha. 
Ardiantari, N. L. P. N., Wiarta, I. W., \& Drs. Ida Bagus Surya Manuaba, S. (2015). Penerapan Pendekatan Saintifik Dengan Penilaian Proyek Untuk Meningkatkan Kemampuan Pemecahan Masalah dan Hasil Belajar Pengetahuan Matematika Tema Cita-Citaku Siswa Kelas IVB SD Negeri 8 Pemecutan. MIMBAR PGSD Undiksha, 3(1). https://doi.org/10.23887/jjpgsd.v3i1.5038

Arikunto, S. (2016). Dasar-dasar Evaluasi Pendidikan. Jakarta: Bumi Aksara.

Arthaningsih, N. K. J., \& Diputra, K. S. (2019). Pengaruh Model Pembelajaran Kooperatif Tipe Two Stay Two Stray melalui Lesson Study terhadap Hasil Belajar Matematika. Journal of Education Technology, 2(4), 128. https://doi.org/10.23887/jet.v2i4.16424

Astami, N. W., Wiarta, I. W., Darsana, I. W., \& Pgsd, J. (2016). Kompetensi Pengetahuan IPS Universitas Pendidikan Ganesha Tujuan Pendidikan Nasional ( Pasal. 17.

Astianawan, I. P., Wiarta, I. W., \& Ganing, N. N. (2016). Penerapan Pendekatan saintifik Berbasis Penilaian Portofolio dapat Meningkatkan Kemampuan Pemecahan Masalah dan Penguasaan Kompetensi Pengetahuan Matematika Siswa Kelas II. E-Journal PGSD Universitas Pendidikan Ganesha, 4(1), 1-10.

Dantes, N. (2014). Desain Eksperimen dan Analisis Data. Yogyakarta: ANDI.

Dwiningrat, I. G. A. A., Suniasih, N. W., \& Drs. Ida Bagus Surya Manuaba, S. (2013). Pengaruh Model Pembelajaran Missouri Mathematics Project Terhadap Kemampuan Pemecahan Masalah Matematika Siswa. MIMBAR PGSD Undiksha, 2(1). https://doi.org/10.23887/jjpgsd.v2i1.2441

Gazali, R. Y. (2016). Pembelajaran Matematika Yang Bermakna. Math Didactic: Jurnal Pendidikan Matematika, 2(3), 181-190. https://doi.org/10.33654/math.v2i3.47

Gilang Azwardi, R. S. (2019). Peningkatan Kemampuan Pemecahan Masalah Matematis Melalui Model Pembelajaran LAPS-Heuristik. Pi: Mathematics Education Journal, 2(2), 62-68.

Gunantara, Suarjana, \& Riastini, N. (2014). Penerapan Model Pembelajaran Problem Based Learning Untuk Meningkatkan Kemampuan Pemecahan Masalah Matematika Siswa Kelas V. Jurnal Mimbar PGSD Universitas Pendidikan Ganesha.

Hidayat, W., \& Sariningsih, R. (2018). Kemampuan Pemecahan Masalah Matematis dan Adversity Quotient Siswa SMP Melalui Pembelajaran Open Ended. JNPM (Jurnal Nasional Pendidikan Matematika). https://doi.org/10.33603/jnpm.v2i1.1027

Kuswari, R., \& . R. (2019). Keefektifan Model Make a Match dengan Media Rorumat Matematika Terhadap Hasil Belajar Siswa. Mimbar Ilmu, 24(1), 20-27. https://doi.org/10.23887/mi.v24i1.17406

Listiani, N. W., Wiarta, I. W., \& Darsana, I. W. (2014). Penerapan Model Pembelajaran Metakognitif Siswa Kelas V Sd Gugus 8 Blahbatuh.

Muliandari, P. T. V. (2019). Pengaruh Model Pembelajaran Kooperatif Tipe NHT (Numbered Head Together) Terhadap Hasil Belajar Matematika. International Journal of Elementary Education, 3(2), 132-140. https://doi.org/10.22202/j1.2017.v3i1.1902

Oktafrianto, O., Relmasira, S. C., \& Asri Hardini, A. T. (2018). Meningkatkan Kemampuan Pemecahan Masalah Matematika Melalui Penerapan Model Pembelajaran Problem Based Learning ( $\mathrm{Pbl}$ ) Berbantuan Media Realia Pada Siswa Kelas Iv Sd. Mimbar Ilmu, 23(3), 218-224. https://doi.org/10.23887/mi.v23i3.16438 
Implementasi Nilai-Nilai Tri Hita Karana dalam Model Pembelajaran Logan Avenue Problem Solving-Heuristik Berpengaruh Positif Terhadap Kemampuan Pemecahan Masalah Matematika

Oktaviani, T., Sulistya Dewi, E. R., \& . K. (2019). Penerapan Pembelajaran Aktif Dengan Metode Permainan Bingo Untuk Meningkatkan Hasil Belajar Matematika. Mimbar Ilmu, 24(1), 47-52. https://doi.org/10.23887/mi.v24i1.17409

Putra, I. G. N. P. A. L. (2019). Pengaruh Model SFAE Berorientasi Tri Hita Karana Terhadap Hasil Belajar IPA. Jurnal Ilmiah Sekolah Dasar, 3(2), 202. https://doi.org/10.23887/jisd.v3i2.17773

Putri, D. K., Sulianto, J., \& Azizah, M. (2019). Analisis Kemampuan Penalaran Ditinjau dari Kemampuan Pemecahan Masalah Matematis. TSCJ (Thinking Skills and Creativity Journal), 2(2), 93-102.

Rahman, I. S., Murnaka, N. P., \& Wiyanti, W. (2018). Pengaruh Model Pembelajaran Laps (Logan Avenue Problem Solving)-Heuristik Terhadap Kemampuan Pemecahan Masalah. WACANA AKADEMIKA: Majalah Ilmiah Kependidikan. https://doi.org/10.30738/wa.v2i1.2556

Riastini, P. N., \& Mustika, I. K. A. (2017). Pengaruh Model Polya Terhadap Kemampuan Pemecahan Masalah Matematika Siswa Kelas V Sd. International Journal of Elementary Education, 1(3), 189. https://doi.org/10.23887/ijee.v1i3.11887

Rila Cahya, P. D. M., Agustika, G. N. S., \& Suniasih, N. W. (2019). Pengaruh Motivasi Berprestasi Terhadap Kemampuan Pemecahan Masalah Matematika. Jurnal Ilmiah Sekolah Dasar, 3(3), 264. https://doi.org/10.23887/jisd.v3i3.14752

Rini, N. P., Shodiqin, A., \& Damayani, A. T. (2019). Keefektifan Model Pembelajaran ICM dan Bertukar Pasangan Berbantuan Media Kartu Angka terhadap Kemampuan Pemecahan Masalah Matematika. Jurnal Ilmiah Sekolah Dasar, 3(1), 1. https://doi.org/10.23887/jisd.v3i1.17173

Shoimin, A. (2014). 68 Model Pembelajaran Inovatif dalam Kurikulum 2013. Yogyakarta:AR-Ruzz Media.

Sugiyono. (2017a). Metode Penelitian Pendidikan Pendekatan Kuantitatif, Kualitatif dan $R \& D$. Bandung: Alfabeta.

Sugiyono. (2017b). Statistika untuk Penelitian. Bandung: Alfabeta.

Suryani, S., \& Iqbal, I. (2018). Pengaruh Model Pembelajaran Logan Avenue Problem Solving (LAPS-Heuristik) Terhadap Hasil Belajar Siswa Kelas VII SMP Negeri 2 Langsa. Al-Qalasadi: Jurnal Ilmiah Pendidikan Matematika. https://doi.org/10.32505/V3I2.1203

Ulia, N. (2016). Peningkatan Pemahaman Konsep Matematika Materi Bangun Datar dengan Pembelajaran Kooperatif Tipe Group Investigation Dengan Pendekatan Saintifik di SD. Jurnal Tunas Bangsa, 3(2), 55-68.

Ulya, H. (2015). Hubungan Gaya Kognitif Dengan Kemampuan Pemecahan Masalah Matematika Siswa. Jurnal Konseling Gusjigang, 1(2). https://doi.org/10.24176/jkg.v1i2.410

Winursiti, N. M. (2017). Penerapan Model Problem Based Learning Berbantuan Reinforcement Simbolik Untuk Meningkatkan Motivasi Dan Hasil Belajar Matematika Siswa Kelas IVB Semester I Tahun Pelajaran 2017/2018 di SD LAB UNDIKSHA. Jurnal Ilmiah Sekolah Dasar. https://doi.org/10.23887/jisd.v1i4.12120

Wulandari, N. P. R., Dantes, N., \& Antara, P. A. (2020). Pendekatan Pendidikan Matematika Realistik Berbasis Open Ended Terhadap Kemampuan Pemecahan Masalah 
Matematika Siswa. Jurnal Ilmiah Sekolah Dasar, 4(2), 131. https://doi.org/10.23887/jisd.v4i2.25103

Yunita Sari, R., Saputra, H. J., \& Azizah, M. (2019). Penerapan Model Numbered Heads Together Berbantu Dakonmatika Pada Kemampuan Pemecahan Masalah Matematika. Jurnal Ilmiah Sekolah Dasar, 3(1), 51. https://doi.org/10.23887/jisd.v3i1.17180

Yusuf, A. Muri, M. P. (2015). Asesmen Dan Evaluasi Pendidikan. Jakarta: Kencana. 